\title{
POZYCJA USTROJOWA PREZYDENTA W PAŃSTWACH BYŁEJ JUGOSŁAWII
}

Instytucja prezydenta jest instytucją szczególną, należy bowiem do tych organów państwowych, które wywołują najwięcej emocji społecznych. Decyduje o tym przede wszystkim jej charakter, łączący cechy jednoosobowego kierownictwa, odpowiedzialności i reprezentacji interesów państwa ${ }^{1}$.

W przypadku państw postjugosłowiańskich istniejąca różnorodność etniczna, religijna i kulturowa miały istotny wpływ na kształtowanie się w tym regionie systemów politycznych, w tym także pozycji ustrojowej głowy państwa. Odmienność religijna i funkcjonowanie w różnych formach kulturowych i etnicznych powodowały, że wytworzyły się odrębne systemy wartości poszczególnych grup, co w określonych sytuacjach mogło doprowadzić do wzrostu napięcia i powstania sytuacji konfliktowej².

Jugosławia od oficjalnego proklamowania republiki w dniu 29 listopada $1945 \mathrm{r}$. nie miała instytucji prezydenta. W pierwszej konstytucji z $1946 \mathrm{r}$. ta funkcja nie była przewidziana, bo nie było jej w konstytucji stalinowskiej ${ }^{3}$ Konstytucja wprowadzała model socjalistycznego parlamentaryzmu - dwuizbowy parlament (Skupsztina Ludowa) składał się z Rady Związkowej oraz Rady Narodowości ${ }^{4}$. Ograniczenie kompetencji parlamentu wynikało $\mathrm{z}$ faktu przekazania kompetencji decyzyjnych do instancji partyjnych (Biura Politycznego Komunistycznej Partii Jugosławii, następnie Prezydium Związku Komunistów Jugosławii), a także wyeliminowaniu ugrupowań opozycyjnych z ław poselskich. Formalnie zgodnie z regulacjami konstytucyjnymi rząd odpowiadał politycznie przed parlamentem ${ }^{5}$.

B. Dziemidok-Olszewska, Instytucja prezydenta w państwach Europy Środkowo-Wschodniej, Lublin 2002, s. 7. R. Łoś, Wojna w Bośni i Hercegowinie (1992-19950), (w:) R. Łoś, J. Reginia-Zacharski (red.), Współczesne konflikty zbrojne, Warszawa 2010, s. 293; zob. W. Paruch, Polityka zdeterminowana przez historię w regionie bałkańskim; status geopolityczny, tożsamość historyczna i procesy narodowotwórcze, (w:) W. Paruch, A. Mironowicz, T. Wicha (red.), Wprowadzenie do studiów wschodnioeuropejskich, t. 1, Błakany: Przeszłość-Teraźniejszość -Przyszłość, M. Podolak (red.), Lublin 2013, s. 151-192.

3 P. Simić, Tito. Zagadka stulecia. D. Ćirlić-Straszyńska, D.J. Ćirlić (tłum.), Wrocław 2009, s. 167.

$4 \quad$ Konstytucja FLRJ z 1946 r., (w:) Nowe konstytucje państw europejskich, L. Gelberg (wstęp), Warszawa 1949.

$5 \quad$ M.J. Zacharias, Komunizm. Federacja. Nacjonalizm. System władzy w Jugosławii 1943-1991. Powstanie - przekształcenia - rozkład, Warszawa 2004, s. 88-89. 
Dnia 13 stycznia 1953 r. została uchwalona ustawa konstytucyjna o podstawach społeczno-politycznego ustroju państwa i o związkowych organach władzy. Niewątpliwie była ona głównym aktem w dziedzinie przemian ustrojowych podejmowanych u schyłku lat czterdziestych XX w. Głosiła, że Jugosławia jest ,socjalistycznym, demokratycznym państwem związkowym suwerennych i równouprawnionych narodów". Określenie to było zasadniczą nowością, ponieważ poprzednia konstytucja z dnia 31 stycznia 1946 r. nie zawierała stwierdzenia o istnieniu socjalistycznych stosunków ustrojowych ${ }^{6}$.

Kolejną innowacją było utworzenie urzędu prezydenta republiki. Zastępował on dawną kolegialną głowę państwa w postaci Prezydium Skupsztyny. Nowy urząd miał być organem polityczno-wykonawczym, realizującym generalną linię polityczną państwa, opracowaną przez parlament. Jednakże rzeczywista, najwyższa władza należała do Josipa Broza-Tito i jego najbliższych współpracowników. Utworzenie urzędu prezydenta i powierzenie go temu politykowi było potwierdzeniem jego roli i znaczenia politycznego w państwie ${ }^{7}$. W 1963 r. doszło do uchwalenia kolejnej konstytucji, która między innymi zmieniła nazwę państwa na Socjalistyczną Federacyjną Republikę Jugosławii. Z przeprowadzonych nowelizacji na szczególną uwagę zasługuje ta z 1971 r., która przewidywała po wygaśnięciu urzędu prezydenta republiki (czyli de facto po śmierci pełniącego ten urząd J. Broz-Tito) zastąpienie tego organu reaktywowanym Prezydium SFRJ ${ }^{8}$.

Od momentu śmierci J. Broza-Tito zaczęło brakować silnego elementu spajającego zamieszkujące Jugosławię narody, jakże różniące się na wielu płaszczyznach - historycznej, kulturalnej i gospodarczej. Do osłabienia więzi przyczyniła się także w znacznym stopniu ostatnia konstytucja związkowa socjalistycznej Jugosławii, przyjęta w 1974 r., która wprowadzała daleko idącą samodzielność podmiotów9 ${ }^{9}$ Po śmierci Broza-Tito w 1980 r. funkcję przewodniczącego Prezydium pełnili rotacyjnie reprezentanci republiki ${ }^{10}$.

Ustrojodawcy państw postjugosłowiańskich stanęli u progu lat 90. XX w. przed koniecznością wyboru systemu rządów adekwatnego do tradycji politycznej, a także sytuacji zewnętrznej, towarzyszącej powstawaniu państwa (konflikt zbrojny w Chorwacji, Bośni i Hercegowinie). Przy wyborze systemu rządów należało uwzględnić także dominujące tendencje w elitach rządzących (silne osobowości - Franjo Tudjman w Chorwacji, Slobodan Milošević w Serbii).

8 K. Składkowski, Formy odpowiedzialności konstytucyjnej w Republice Chorwacji, (w:) S. Grabowska, R. Grabowski (red.), Formy odpowiedzialności konstytucyjnej w państwach europejskich, Toruń 2010, s. 77.

9 K. Krysieniel, Ewolucja systemu politycznego Bośni i Hercegowiny w latach 1990-1995, (w:) P. Chmielewski, S. L. Szczesio (red.), Bałkany Zachodnie między przeszłością a przyszłością, Łódź 2013, s. 225.

10 J. Wojnicki, Prawo wyborcze na urząd prezydenta republiki w Republice Serbii, (w:) S. Grabowska, R. Grabowski (red.), Prawo wyborcze na urząd prezydenta w państwach europejskich, Warszawa 2007, s. 168. 
Transformacja ustrojowa w państwach postjugosłowiańskich zapoczątkowała odejście od państwa typu socjalistycznego oraz powolną budowę państwa demokratycznego. Wybór demokratycznego sposobu sprawowania władzy był wyborem strategicznym, choć w przypadku republik postjugosłowiańskich pozostawał w cieniu powstawania nowych organizmów państwowych. Sytuacja powyższa odróżniała wydarzenia w Europie Środkowej od tych, które miały miejsce na terenach Jugosławii. Należy zauważyć, iż kształtowanie się systemów demokratycznych nie następowało jednakże bezproblemowo, wśród republik postjugosłowiańskich można mówić o zróżnicowanym jego tempie ${ }^{11}$.

Większość konstytucji państw postjugosłowiańskich kształtuje parlamentarny system rządów i są one nowoczesnymi konstytucjami, które w swoich postanowieniach odpowiadają standardom konstytucjonalizmu zarówno europejskiego, jak i światowego.

Egzekutywa, czyli władza wykonawcza w analizowanych państwach występuje w postaci dwuczłonowej, należy do prezydenta oraz rządu i zajmuje się całokształtem spraw związanych z polityką wewnętrzną i zagraniczną. Wszędzie występuje tzw. dualizm egzekutywy ${ }^{12}$. Generalnie można wymienić wśród państw postjugosłowiańskich republiki parlamentarno-gabinetowe (Słowenia, Macedonia oraz Chorwacja od 2000 roku) oraz republiki z aktywną rolą prezydenta. Realna pozycja głowy państwa wynika z praktyki konstytucyjnej oraz przepisów ustaw zasadniczych (Chorwacja w okresie prezydentury F. Tudjmana oraz Serbia za czasów S. Miloševicia $)^{13}$. Głowa państwa może sprawować albo rolę arbitra w systemie politycznym, albo aktywnego organu w systemie rządów. Należy szczególnie podkreślić, iż po alternacji władzy w Chorwacji, która się dokonała w 2000 roku, nastąpiło formalne odejście od systemu z silnym komponentem prezydenckim do systemu parlamentarno-gabinetowego, uwieńczone stosowną nowelizacją konstytucji ${ }^{14}$.

Konstrukcja instytucji prezydenta podobnie jak ukształtowanie innych rozwiązań ustrojowych, nie jest i nie może być procesem sztucznym, abstrakcyjnym, oderwanym od rzeczywistości politycznoprawnej danego państwa. Tworzenie instytucji prezydenta powinno uwzględniać historyczne tradycje narodu, być dostosowane do społecznego otoczenia, politycznoprawnych warunków funkcjonowania systemu i odpowiadać ukształtowanym stosunkom i oczekiwaniom społecznym ${ }^{15}$.

\footnotetext{
11 J. Wojnicki, Ewolucja systemów politycznych państw postjugosłowiańskich (casus Bośni i Hercegowiny, Chorwacji, Macedonii, Serbii i Czarnogóry oraz Słowenii), on-line, Studia i Komentarze Instytutu Europy Środkowo -Wschodniej, nr 10 Czasopismo online Instytutu Europy Środkowo-Wschodniej, 2008. www. iesw.lublin. pl (data dostępu: 30.06.2015 r.).

12 W. Sokół, Transformacja ustrojowa państw Europy Środkowo-Wschodniej-próba bilansu, (w:) W. Sokół, M. Żmigrodzki (red.), Systemy polityczne państw Europy Środkowo-Wschodniej, Lublin 2005, s. 31-32.

13 Zob. Konstytucja Republiki Chorwacji, A. i L. Garliccy (wstęp), Warszawa 1995; R. Markowić, The Constitution of Republic of Serbia, http://www.serbia.info.com (data dostępu: 10.08.2015 r.).

14 J. Wojnicki, Ewolucja systemów politycznych op.cit. zob. D. Mikucka-Wójtowicz, Demokratyczna transformacja w Serbii i Chorwacji w latach 1990-2010, Kraków 2014, s. 142.

15 B. Dziemidok-Olszewska, Instytucja..., op. cit., s. 86.
} 
W analizowaniu pozycji ustrojowej głowy państwa należy uwzględnić następujące czynniki; po pierwsze - sposób wyboru, po drugie - zakres przyznanych prezydentowi kompetencji wykonawczych i po trzecie - odpowiedzialność konstytucyjno-prawną. W państwach byłej Jugosławii istnieje zauważalna tendencja do stosowania procedury powszechnych wyborów prezydenckich. Jedynym państwem, w którym prezydent wybierany jest w wyborach pośrednich jest obecnie Kosowo. Poza Kosowem wybory są powszechne, równe, bezpośrednie, oparte na zasadzie tajności głosowania. Kandydaci muszą być obywatelami danego państwa, mieć ukończone średnio 35-40 lat, korzystać z pełni praw publicznych. Kadencja prezydentów w Bośni i Hercegowinie wynosi 4 lata, w pozostałych państwach 5 lat. Istnieje możliwość ponownego wyboru z reguły tylko raz.

W Kosowie prezydent wybierany jest w głosowaniu tajnym przez Zgromadzenie na 5-letnią kadencję ${ }^{16}$. Kandydat musi uzyskać poparcie kwalifikowanej większości deputowanych (2/3). Ponownie może być wybrany tylko raz ${ }^{17}$.

W przypadku Bośni i Hercegowiny mamy do czynienia z kolegialną głową państwa. Funkcję tę pełni trzyosobowe Prezydium Bośni i Hercegowiny ${ }^{18}$ wybierane w wyborach powszechnych na 4 lata, składające się z Serba, Chorwata i Bośniaka. Jego członkowie pełnią rotacyjnie, zmieniając się co 8 miesięcy, funkcje Przewodniczącego Prezydium i jego zastępców. Dwaj członkowie Prezydium, Bośniak i Chorwat, wybierani są na terytorium FBiH, a trzeci, Serb, na terytorium RS. Wynika to $\mathrm{z}$ faktu, że tereny BiH zamieszkują trzy główne grupy etniczne - Bośniacy, Serbowie i Chorwaci - wyznające trzy religie: islam, prawosławie i katolicyzm ${ }^{19}$.

Wśród czynników wyznaczających status prezydenta w państwie jednym z najważniejszych jest zakres przyznanych mu kompetencji. Stanowi on punkt wyjścia przy kreowaniu instytucji prezydenta, ponadto musi być jasno i precyzyjnie sformułowany oraz adekwatny do przypisanych prezydentowi funkcji ${ }^{20}$.

Najważniejsze funkcje prezydentów są typowe dla głowy państwa w systemach parlamentarnych i prezydenckich:

- reprezentowanie państwa $\mathrm{w}$ stosunkach zewnętrznych i wewnętrznych za granicą,

- podpisywanie ustaw,

- przedkładanie parlamentowi kandydatur na stanowiska premiera oraz członków rządu,

- mianowanie i odwoływanie, na wniosek rządu, ambasadorów,

Zob. Konstytucja Republiki Kosowa, Rzeszów 2010.

B. Pawłowski System polityczny Kosowa, (w:) T. Bichta, M. Podolak (red.), Systemy polityczne państw bałkańskich, Lublin 2012, s. 287.

Zwane także Prezydencją, ponieważ w oryginalnym, czyli anglojęzycznym tekście konstytucji organ ten określany jest jako Presidency. System rotacyjny sprawił, że w latach 1995-2010 zmiana na stanowisku przewodniczącego Prezydium dokonywana była aż 20 razy.

J. Olchowski, System polityczny Bośni i Hercegowiny, (w:) Systemy polityczne państw bałkańskich, Lublin, s. 112. Zob. J. Ciapała, Prezydent w systemie ustrojowym Polski (1989-1997), Warszawa 1999, s. 231-233. 
- przyjmowanie listów uwierzytelniających od przedstawicieli dyplomatycznych innych państw,

- stosowanie prawa łaski,

- nadawanie odznaczeń, orderów i tytułów honorowych.

Prezydenci z reguły nie posiadają prawa inicjatywy ustawodawczej. Wyjątek stanowi prezydent Kosowa. Nieliczni posiadają prawo inicjatywy w zakresie zmiany konstytucji (Chorwacja, Czarnogóra, Kosowo, Macedonia, Serbia) oraz prawo weta zawieszającego (Czarnogóra, Kosowo, Macedonia, Serbia) ${ }^{21}$.

Podpisywanie ustaw należy do tradycyjnych kompetencji głowy państwa. Teoretycznie podpisanie ustawy polega na stwierdzeniu przez uprawniony konstytucyjnie organ, najczęściej głowę państwa, że ustawa o danej treści została uchwalona przez parlament ${ }^{22}$. Prawo odmowy podpisania ustaw, nazywane potocznie prawem weta, oznacza brak zgody państwa na obowiązywanie aktu uchwalonego przez parlament. Odmowa podpisania nie jest, jak podpisanie aktem deklaratoryjnym, prezydent odmawiając podpisu nie działa w charakterze symbolu państwa, lecz włącza się w proces decyzyjny. Natomiast obie te instytucje, podpisanie i zawetowanie ustawy, wprowadzają element równowagi pomiędzy władzami. Odgrywają także rolę prewencyjną, dyscyplinują i mobilizują parlament do podejmowania działań racjonalnych merytorycznie i zgodnych z obowiązującym prawem ${ }^{23}$.

W Bośni i Hercegowinie Prezydium podejmuje decyzje w drodze konsensusu. Jeśli jeden z członków Prezydium zgłosi swój sprzeciw wobec decyzji, po trzech dniach referowana ona jest odpowiednio przed Zgromadzeniem Narodowym RS lub Izbą Narodów FBiH. W sytuacji, gdy 2/3 głosujących opowie się przeciwko decyzji, zostaje ona odrzucona. Oznacza to, że blokowanie decyzji Prezydium jest stosunkowo łatwe ${ }^{24}$. W Chorwacji prezydent nie posiada prawa inicjatywy ustawodawczej. Jego rola w procesie legislacyjnym sprowadza się do uregulowania zawartego w art. 88 Konstytucji stanowiącym, że prezydent podpisuje ustawę przedłożoną przez Sabor w ciągu 8 dni od jej otrzymania. Prezydent nie dysponuje prawem weta, ale może przed podpisaniem ustawy odesłać ją do Trybunału Konstytucyjnego, z wnioskiem o zbadanie zgodności z konstytucją ${ }^{25}$. Prezydent Kosowa promulguje ustawy przyjęte przez Zgromadzenie w ciągu 8 dni od dnia ich doręczenia, posiada także prawo weta zawieszającego, polegającego na możliwości odesłania do Zgromadzenia ustawy przyjętej przez Zgromadzenie w celu jej ponownego rozważenia ${ }^{26}$. nowicz, T. Wicha (red.), Wprowadzenie do studiów wschodnioeuropejskich, t. 1, Bałkany: Przeszłość-Teraźniejszość-Przyszłość, M. Podolak (red.), Lublin 2013, s. 261. etapach procesu legislacyjnego, Warszawa 1999, s. 11-19. Ibidem, s. 226.

J. Olchowski, System polityczny..., op. cit., s. 113.

M. Podolak, Systemy polityczne..., op. cit., s. 218.

K. Pawłowski, System polityczny..., op. cit., s. 288. 
Prezydentowi Macedonii nie przysługuje prawo inicjatywy ustawodawczej, a prezydenckie weto wobec uchwalonej już ustawy nie jest ingerencją $\mathrm{w}$ sam proces legislacji. Wobec powyższego możliwości wpływu prezydenta na tok pracy parlamentu, a także na bieżącą politykę, są znikome ${ }^{27}$. Prezydent Serbii podpisuje ustawy parlamentu lub może zwrócić je do ponownego rozpatrzenia z pisemnym wyjaśnieniem. W przypadku ustaw przyjętych w trybie zwykłym ma na to 15 dni, a w przypadku ustaw przyjętych w trybie pilnym 7 dni. Ustawa może być ponownie przyjęta przez Zgromadzenie Narodowe większością głosów ogólnej liczby członków Zgromadzenia. Prezydent jest zobowiązany do ogłaszania nowo przyjętej ustawy (art. 113 Konstytucji ${ }^{28}$. Konstytucja Słowenii, w odróżnieniu od innych państw nie przyznaje głowie państwa inicjatywy ustawodawczej i prawa weta zawieszającego w stosunku do ustaw. Prezydent został także pozbawiony prawa zarządzania referendum ustawodawczego. W materii procesu legislacyjnego uprawnienia prezydenta ogranicza się wyłącznie do promulgacji ustaw ${ }^{29}$.

Istotnym uprawnieniem jest prawo skrócenia kadencji parlamentu w określonych konstytucyjnie sytuacjach:

1. nieuchwalenie budżetu państwa w konstytucyjnym terminie np. Chorwacja;

2. nieudzielenie wotum zaufania utworzonemu rządowi w konstytucyjny terminie, np. Czarnogóra, Kosowo, Serbia, Słowenia;

3. udzielenie wotum nieufności dla rządu, np. Chorwacja, Serbia;

4. gdy parlament nie poprze wniosku premiera o wotum zaufania i w konstytucyjnym terminie nie wybierze nowego szefa rządu, np. Słowenia ${ }^{30}$.

Kolejnym istotnym uprawnieniem głowy państwa jest udział w tworzeniu rządu. Ten rodzaj kompetencji wyznacza i porządkuje wzajemne relacje głowy państwa i rządu wewnątrz dualistycznej egzekutywy, jaka został przyjęta w analizowanych państwach. Proces powoływania premiera i rządu jest procedurą, w której nie wszystkie dokonywane są uregulowane w normach prawnych, a zwyczaje i kultura polityczna posiadają równorzędne znaczenie. Natomiast prawne regulacje tego procesu w decydującym stopniu zależne są od przyjętego systemu rządów. Prezydenci mają prawo desygnowania kandydata na premiera oraz na jego wniosek członków rządu.

Prezydium Bośni i Hercegowiny nominuje premiera, który, za aprobatą większości Izby Reprezentantów, tworzy Radę Ministrów Bośni i Hercegowiny, czyli centralny rząd, składający się z 9 ministrów (w tym najwyżej 6 z FBiH). Zarówno premier, jak i ministrowie, mają po dwóch zastępców - i tu również obowiązuje parytet narodowościowy, co ma na celu zapewnienie wszystkim narodom konstytucyj- 
nym równego udziału w sprawowaniu władzy na szczeblu centralnym. Do podjęcia jakiejkolwiek decyzji potrzebna była zgoda wszystkich trzech, tj. premiera/ministra i jego zastępców, ponieważ tak jak w przypadku Prezydium w istocie byli oni sobie równi (ich także dotyczyła zasada rotacji) - dopiero w 2002 roku Wysoki Przedstawiciel zniósł tę zasadę ${ }^{31}$.

W Chorwacji prezydent powołuje i odwołuje premiera, a na wniosek premiera powołuje i odwołuje wicepremierów oraz pozostałych członków rządu ${ }^{32}$. Prezydent ma prawo uczestniczyć w posiedzeniach rządu republiki, jest on przewodniczącym posiedzenia rządu, na którym jest obecny, może zwoływać posiedzenia rządu i wprowadzać do porządku obrad swoje punkty ${ }^{33}$.

W przypadku Czarnogóry powołanie nowego rządu jest procedurą złożoną i podzieloną pomiędzy uprawnienia prezydenta Republiki oraz Zgromadzenia. Pierwszy krok należy do głowy państwa - prezydent posiada konstytucyjny obowiązek przedstawienia Skupsztinie w ciągu 30 dni od dnia ukonstytuowania się parlamentu mandatariusza (którego należy traktować jako kandydata na premiera). Mandatariusz jest zobowiązany do przedstawienia Zgromadzeniu oświadczenia o programie i składzie rządu. Konstytucja określa wyraźny termin na czynności związane z formowaniem nowego rządu oraz sankcję za ich niedotrzymanie. Skupsztina ulega bowiem rozwiązaniu w przypadku, gdy nie wybierze rządu w ciągu 90 dni od zgłoszenia przez prezydenta pierwszego mandatariusza (art. 92 konstytucji). Parlament decyduje o zaakceptowaniu programu i składu nowego rządu w jednym głosowaniu (art. 103 konstytucji). Konstytucja przyznaje Skupsztinie uprawnienie do wyboru oraz odwołania premiera oraz pozostałych członków rządu (art. 82 konstytucji). Ustrojodawca stanowi, iż do przegłosowania wspomnianych decyzji wymagana jest większość ustawowej liczby deputowanych - 41 z ogólnej liczby 81 (art. 91 konstytucji) ${ }^{34}$.

Realizując kompetencje kreacyjne prezydent Kosowa mianuje kandydata na stanowisko premiera w oparciu o propozycję personalną, przedłożoną mu przez partię polityczną posiadającą większość w Zgromadzeniu lub koalicję partii politycznych posiadającą taką większośćs ${ }^{35}$.

Prezydent Republiki Macedonii jest obowiązany w ciągu 10 dni od ukonstytuowania się Zgromadzenia powierzyć misję tworzenia rządu kandydatowi partii lub koalicji, która zdobyła większość w Zgromadzeniu. Mandatariusz, w terminie do 20 dni od daty powierzenia mu misji, przedstawia Zgromadzeniu skład i program rządu. $\mathrm{Na}$ wniosek mandatariusza i na podstawie przedstawionego programu, Zgromadzenie w głosowaniu akceptuje rząd większością głosów ogólnej liczby deputowanych (konstytucja art. 10).

\footnotetext{
31 W. Walkiewicz, Jugosławia. Państwa sukcesyjne, Warszawa 2009, s. 353.

32 J. Wojnicki, Przeobrażenia ustrojowe państw post jugosłowiańskich (1990-2003), Pułtusk 2003, s. 148.

33 Ibidem, s. 149.

34 J. Wojnicki, Instytucja Rządu Republiki Czarnogóry w systemie organów państwa http://kolegia.sgh.waw.pl, (data dostępu: 10.09.2015 r.)

35 K. Pawłowski, System polityczny..., op. cit., s. 288.
} 
Proces powoływania rządu w Serbii został zaliczony do kompetencji prezydenta oraz Zgromadzenia Narodowego. Inicjatywa we wspomnianym zakresie należy do głowy państwa. Do uprawnienia Prezydenta Republiki należy wyznaczenie kandydata na premiera. Następnym krokiem jest podjęcie się przez premiera misji stworzenia gabinetu. Zakończeniem tego etapu jest wystąpienie szefa rządu przed Zgromadzeniem Narodowym w sprawie programu oraz składu gabinetu. Do podjęcia decyzji przez Zgromadzenie Narodowe wymagana jest zgoda większości ogólnej liczby deputowanych (co najmniej 126 z 250 ogólem - art. 127 Konstytucji) ${ }^{36}$.

Kompetencje prezydenta Słowenii w świetle konstytucji są dość ograniczone, również w odniesieniu do rządu. Prezydent, po konsultacjach, ma wyłączne prawo przedstawienia kandydata na premiera w ramach pierwszego wyboru szefa rządu. Może również uczestniczyć w kolejnych wariantach powoływania premiera poprzez proponowanie swojego kandydata na to stanowisko. Zgodnie z zasadami ustawy o rządzie prezydent jest informowany przez gabinet o kluczowych zagadnieniach polityki państwa ${ }^{37}$.

Kompetencje prezydenta w stosunku do władzy sądowniczej są znacznie skromniejsze niż w stosunku do parlamentu czy rządu, z uwagi na szczególną pozycję i znaczną niezależność władzy sądowniczej. Uprawnienia prezydenta dotyczą głównie prawa łaski, powoływania sędziów i organów władzy sądowniczej, co należy do tradycyjnych atrybutów głowy państwa, a także występowania z wnioskami do Sądów Konstytucyjnych i Trybunałów ${ }^{38}$.

Miejsce głowy państwa w stosunkach zewnętrznych określone jest według norm zwyczajowych jako tzw. Ius repraesentationis omnimodae, czyli prawa nieograniczonego reprezentowania państwa w kontaktach międzynarodowych. Oświadczenia głowy państwa traktowane są jako równoznaczne z wolą państwa, a tym samym jako wywołujące skutki prawne w stosunkach międzynarodowych ${ }^{39}$.

Rozmieszczenie kompetencji w dziedzinie spraw zagranicznych wewnątrz egzekutywy zależy od regulacji wzajemnych stosunków między prezydentem a rządem, a te są bezpośrednio związane z przyjętym systemem rządów. Rola prezydenta w dziedzinie stosunków zagranicznych może mieć charakter wyłącznie ceremonialny lub może być on szefem polityki zagranicznej, która stanowi istotną domenę jego aktywności. Wzajemne relacje między prezydentem a rządem mogą przyjmować formę: przewagi prezydenta, przewagi rządu lub wzajemnej równowagi. Pozycja prezydenta $\mathrm{w}$ dziedzinie spraw zagranicznych jest bowiem pochodną jego pozycji ustrojowej, może wynikać ze statusu głowy państwa lub statusu organu władczo-politycznego ${ }^{40}$. 
Prezydent nie ponosi odpowiedzialności za akty podjęte w czasie sprawowania swego urzędu. Prezydenta można odwołać z urzędu z powodu naruszenia Konstytucji i popełnienia ciężkiego przestępstwa ${ }^{41}$. W przypadku odpowiedzialności konstytucyjnej w tradycyjnym ujęciu chodzi o postępowanie karne z osobliwościami dotyczącymi podmiotu odpowiedzialności, organu decydującego, piastowanego urzędu oraz sankcji. Zarówno immunitet osób pełniących funkcje konstytucyjne (m.in. prezydent, sędzia, parlamentarzyści), jak i odpowiedzialność konstytucyjna stanowi naruszenie ogólnej zasady równości wobec prawa. Naruszenie tej zasady wynika także z faktu, że określona grupa podmiotów jest pociągana do odpowiedzialności przed szczególnym organem pod groźbą szczególnej sankcji ${ }^{42}$.

Wyjątkiem wśród analizowanych państw jest ponownie Bośnia i Hercegowina, w której zauważalny jest brak na poziomie prawa federalnego pojęcia odpowiedzialności konstytucyjnej. Ustawa zasadnicza nie przewiduje żadnej możliwości odwołania osób zajmujących najwyższe stanowiska w państwie: czy to członków kolegialnego Prezydium BiH, czy też Rady Ministrów. Takiej prawnej możliwości nie przewidują także akty prawne niższego rzędu ${ }^{43}$.

We wszystkich państwach wniosek o odwołanie prezydenta jest rozpatrywany przez parlament i musi być on poparty przez co najmniej kwalifikowaną większość wszystkich jego członków. Uchwała parlamentu jest przesyłana do Sądu Konstytucyjnego, który orzeka o winie prezydenta i ogłasza jego odwołanie ze stanowiska.

W przypadku państw byłej Jugosławii wpływ na kształtowanie się przyszłych systemów politycznych miało zróżnicowanie etniczno-religijne tego regionu. To zróżnicowanie zdecydowało, że hasłem przewodnim przeobrażeń polityczno-ustrojowych w poszczególnych republikach jugosłowiańskich była w mniejszym stopniu demokratyzacja systemu polityczno-ustrojowego, a w większym stopniu budowa niezależnych organizmów państwowych ${ }^{44}$.

Prezydenci w analizowanych państwach pełnią funkcje reprezentacyjne i posiadają ograniczone uprawnienia w stosunku do parlamentu i rządu. Rzeczywisty wpływ prezydenta na przebieg spraw w państwie zależy w dużym stopniu od jego autorytetu i osobowości. Prezydenci sprawując funkcję reprezentacyjną, zarówno na arenie międzynarodowej, jak i w państwie spełniają funkcję integracyjną. Rola prezydenta jako czynnika integrującego wyraziła się $\mathrm{w}$ promowaniu wstąpienia

\footnotetext{
41 Por. B. Dziemidok-Olszewska, Kształtowanie się odpowiedzialności prawnej prezydenta III Rzeczypospolitej, (w:) B. Dziemidok-Olszewska, T. Bichta (red.), Dwadzieścia lat demokratyzacji systemu politycznego RP, Lublin 2011, s. 101-129.

42 J. Filip, Pojęcie oraz rodzaje odpowiedzialności konstytucyjnej, (w:) S. Grabowska, R. Grabowski (red.), Formy odpowiedzialności konstytucyjnej w państwach europejskich, Toruń 2010, s. 21-22.

43 K. Krysieniel, Formy odpowiedzialności konstytucyjnej w Bośni i Hercegowinie, (w:) Formy odpowiedzialności konstytucyjnej, s. 67.

44 J. Wojnicki, Formowanie się nowych państw w Europie Środkowo-Wschodniej po 1990 roku (casus Słowenii, Chorwacji, Macedonii oraz Bośni i Hercegowiny), (w:) S. Wróbel (red.), Współczesne państwo. Wybrane problemy, Poznań-Chorzów 2009, s. 307.
} 
Chorwacji i Słowenii do Unii Europejskiej i NATO oraz zaangażowaniu w narodowe pojednanie i zlikwidowanie podziałów z przeszłości ${ }^{45}$.

\section{BIBLIOGRAFIA}

Ciapała Jerzy. 1999. Prezydent w systemie ustrojowym Polski (1989-1997), Warszawa: Wydawnictwo Sejmowe.

Dziemidok-Olszewska Bożena. 2002. Instytucja prezydenta w państwach Europy Środkowo-Wschodniej. Lublin: Wydawnictwo UMCS.

Dziemidok-Olszewska Bożena. 2011. Kształtowanie się odpowiedzialności prawnej prezydenta III Rzeczypospolitej. W Dwadzieścia lat demokratyzacji systemu politycznego RP, 101-116. Lublin: Wydawnictwo UMCS.

Filip Jan. 2010. Pojęcie oraz rodzaje odpowiedzialności konstytucyjnej. W Formy odpowiedzialności konstytucyjnej w państwach europejskich. 19-32. Toruń: Wydawnictwo Adam Marszałek.

Krysieniel Krzysztof. 2013. Ewolucja systemu politycznego Bośni i Hercegowiny w latach 19901995.W Bałkany Zachodnie między przeszłością a przyszłością.225-242. Łódź: Wydawnictwo Uniwersytetu Łódzkiego.

Krysieniel Krzysztof. 2010. Formy odpowiedzialności konstytucyjnej w Bośni i Hercegowinie. W Formy odpowiedzialności konstytucyjnej w państwach europejskich, 65-69.Toruń: Wydawnictwo Adam Marszałek.

Łoś Robert. 2010. Wojna w Bośni i Hercegowinie (1992-19950). W Współczesne konflikty zbrojne. 292-308. Warszawa: Wydawnictwo Naukowe PWN.

Mikucka-Wójtowicz Dominika. 2014. Demokratyczna transformacja w Serbii i Chorwacji w latach 1990-2010. Kraków: Wydawnictwo LIBRON- Filip Lohner.

Mikuli Piotr. 2004. System konstytucyjny Słowenii. Warszawa: Wydawnictwo Sejmowe.

Mizerski Edmund. 1995. Geneza i konstytucyjna pozycja parlamentu związkowego w Jugosławii w latach 1941-1990. Torun.

Olchowski Jakub. 2012. System polityczny Bośni i Hercegowiny. W Systemy polityczne państw bałkańskich, 93-126. Lublin: Wydawnictwo UMCS.

Paruch Waldemar. 2013. Polityka zdeterminowana przez historię w regionie bałkańskim; status geopolityczny, tożsamość historyczna i procesy narodowotwórcze W Wprowadzenie do studiów wschodnioeuropejskich, t. 1, Błakany: Przeszłość-Teraźniejszość-Przyszłość, 151-192. Lublin: Wydawnictwo UMCS.

Pawłowski Konrad. 2012. System polityczny Kosowa. W Systemy polityczne państw bałkańskich, 271-302, Lublin: Wydawnictwo UMCS.

Podolak Małgorzata. 2013. Systemy polityczne w regionie - między autorytaryzmem, a demokracją. W Wprowadzenie do studiów wschodnioeuropejskich, t. 1. Błakany: Przeszłość-Teraźniejszość -Przyszłość, 235-274. Lublin: Wydawnictwo UMCS. 
Simić Pero. 2009. Tito. Zagadka stulecia. Tłum. Danuta Cirlić-Straszyńska, Dorota Jovanka Ćirlić. Wrocław: Wydawnictwo Dolnośląskie.

Składkowski Konrad. 2010. Formy odpowiedzialności konstytucyjnej w Republice Chorwacji. W Formy odpowiedzialności konstytucyjnej w państwach europejskich.76-81. Toruń: Wydawnictwo Adam Marszałek.

Sokół Wojciech. 2012. System polityczny Słowenii. W Systemy polityczne państw bałkańskich, 385422. Lublin: Wydawnictwo UMCS.

Sokół Wojciech. 2005. Transformacja ustrojowa państw Europy Środkowo-Wschodniej-próba bilansu. W Systemy polityczne państw Europy Środkowo-Wschodniej, 15-71. Lublin: Wydawnictwo UMCS.

Sutor Julian. 1993. Prawo dyplomatyczne i konsularne. Warszawa: Wydawnictwo PWN.

Walkiewicz Wiesław. 2009. Jugosławia. Państwa sukcesyjne. Warszawa: Wydawnictwo Trio.

Wojnicki Jacek. 2009. Formowanie się nowych państw w Europie Środkowo-Wschodniej po 1990 roku (casus Słowenii, Chorwacji, Macedonii oraz Bośni i Hercegowiny). W Współczesne państwo. Wybrane problemy. 307-329. Poznań-Chorzów: Wydawnictwo Wyższej Szkoły Bankowej.

Wojnicki Jacek. 2010. „Instytucja Rządu Republiki Serbii w systemie organów władzy”. Przegląd Prawa Konstytucyjnego 2-3: 113-130.

Wojnicki Jacek. 2007. Prawo wyborcze na urząd prezydenta republiki w Republice Serbii. W Prawo wyborcze na urząd prezydenta w państwach europejskich. 167-175. Warszawa: Oficyna a Wolters Kluwer buissnes .

Wojnicki Jacek. 2003. Przeobrażenia ustrojowe państw postjugosłowiańskich (1990-2003). Pułtusk: Wyższa Szkoła Humanistyczna im. Aleksandra Gieysztora .

Zacharias Michał Jerzy. 2004. Komunizm. Federacja. Nacjonalizm. System władzy w Jugosławii 19431991. Powstanie - przekształcenia-rozkład. Warszawa: NERITON.

Zaleśny Jacek. 1999. Partycypacja głowy państwa w ostatnich etapach procesu legislacyjnego. Warszawa: Dom Wydawniczy i Handlowy Elipsa. 


\section{EXECUTIVE STATUS IN POST YUGOSLAVIAN STATES}

In this article the political position of the institution of presidency is discussed in the context of the independent states that have emerged from the former Yugoslavia. It can be said that parliamentary cabinet systems, in which the head of state performs representative and integration functions, are appearing in these post-Yugoslavian states. One influence on forming the institution of presidency is the diversity and multiculturalism which exists in this region of Europe.

Apart from the legal constitutional position of the president, theeffectivenesses of his power is ranked among such factors as: political personality, style of the administration and the political situation in the state.

Keywords: Political system, head of state, post-Yugoslavian states

Słowa kluczowe: System polityczny, instytucja prezydenta, państwa postjugosłowiańskie 